\title{
Superior Hybrid Corn Variety Selection using AHP Method
}

\author{
Aji Santoso, Phong Thanh Nguyen, M. Ilayaraja, K. Shankar, Satria Abadi, Wahidah Hashim, \\ Andino Maseleno
}

\begin{abstract}
Corn is one of the economic support from the agricultural sector which has recently shown a positive impact with increasing production from year to year, it has increased to $12.49 \%$ per year and is predicted to increase. Increasing corn production has had a very positive impact on economy, reduced imports and increased exports greatly helped Indonesia in improving the economy. Therefore the government strongly supports corn farming in Indonesia so that the government and farmers are aggressively looking for superior seeds for planting, with a faster harvest period and resistance to pests, a decision support system is made to select superior corn varieties with AHP method (analytical hierarchy process). In order to facilitate farmers in selecting superior and profitable types of corn. With this decision support system, it is expected that it can help in selecting the right and accurate corn varieties according to the farmer expectation.
\end{abstract}

Keywords : DSS, AHP, Hybrid Corn.

\section{INTRODUCTION}

\subsection{Background}

Indonesia is a country located on the equator, it causes Indonesia having very fertile soil and easy to grow various types of plants such as crops, vegetables, fruits, medicines and even spices that flourish in Indonesia, it is what makes Indonesia is rich in natural resources. A plant that grows easily in Indonesia is corn, corn is the second staple food after rice, besides that, corn can be processed into various types of processed food such as flour, sugar, cooking oil, ethanol, even animal feed and industrial raw materials, Corn production in Indonesia is increasing from year to year according to the Directorate General of Crops (DG TP) Ministry of Agriculture, corn production in the last 5 years has increased by an average of $12.49 \%$ per year . this is very

Revised Manuscript Received on July 22, 2019

* Correspondence Author

Aji Santoso, Department of Information Systems, STMIK Pringsewu, Lampung, Indonesia.

Phong Thanh Nguyen*, Department of Project Management, Ho Chi Minh City Open University, Vietnam. E-mail: phong.nt@ou.edu.vn

M. Ilayaraja, Department of Computer Science and Information Technology, Kalasalingam Academy of Research and Education, Krishnankoil, India. E-mail: ilayaraja.m@klu.ac.in

K. Shankar, Department of Computer Applications, Alagappa University, Karaikudi, India.

Satria Abadi, Department of Information Systems, STMIK Pringsewu, Lampung, Indonesia.

Wahidah Hashim, Institute of Informatics and Computing Energy, Universiti Tenaga Nasional, Malaysia.

Andino Maseleno, Institute of Informatics and Computing Energy, Universiti Tenaga Nasional, Malaysia

good because it will raise the economy of Indonesia.

Decision Support Systems (DSS) is a system built to solve various managerial problem designed to develop the effectiveness and productivity of managers to solve problems with the help of computer technology [1][2]. Corn is an important commodity after rice. The need of corn continues to increase every year. To meet these needs, it is necessary to increase production and productivity, one of which is through the use of superior hybrid varieties .

Generally the research is conducted to solve a problem in life [3]. In this study it was conducted to increase domestic corn production in order to be able to meet domestic needs and improve the economy [4]. A study was conducted on hybrid corn varieties which had the highest corn production compared to the corn species. others. This study utilized a decision support system to help selection of superior hybrid corn varieties to be more effective and efficient, and using the AHP method (analytical hierarchy process).

This research was conducted because corn is one of the commodities that the government pays attention and lately it has shown a positive signal by increasing production from year to year, but the difficulty and the lack of knowledge in selecting seeds cause many farmers to worry about unsatisfactory yields and tend to not be on target while the need for corn is increasing in line with population growth in Indonesia

This research aimed to help farmers in selecting superior hybrid corn varieties to increase corn production and reduce the risk of large losses because of crop failure.

\subsection{Problem Formulation}

Based on the background above, it can be formulated that how to select hybrid corn variety by using decision support system and AHP method?

\subsection{Research Objective and Benefit}

The purpose of this research was to result a decision support system for selecting hybrid corn varieties, so that this system can be beneficial for corn farmers and is expected to be a reference and comparison material for future researchers. 


\section{THEORETICAL BASE}

\subsection{Decision Support System}

Decision support system is a process of selecting actions between various alternatives to achieve goals [5]. One of the most important components in the decision-making process is the activity of collecting information on problems needed for decisions to resolve them [6]. Decision making can be individuals or groups, both for their own interests and group interests [7]. The quality of the decision resulted will be far if using a computer-based system by utilizing data and models to solve problems to be processed [8]

\subsection{Hybrid Corn Variety}

Hybrid varietiy is the first generation of crosses between two or more populations that have the superiority of their respective characteristics to get a better combination than the previous generation. Hybrid varietu yield is higher than composite varieties because hybrid varieties combine the dominant genes of desired character from their constituent individuals. Hybrid varieties provide higher benefits when planted on high productivity land.

The productivity of superior varieties of corn is determined by genetic and environmental factors. Hybrid variety is carefully produced varieties in a controlled environment. There are several types of varieties, namely:

1. Single cross, this is the result of a cross between two pure strains that are not related to each other.

2. Three-lane cross, that is the result of a cross between a single cross with one pure line.

3. Double cross involves four pure strain that are is not related to each other.

4. Shoot cross, i.e. crossing through pollinating a pure strain with a population that results pollen that is genetically mixed

\subsection{Analytical Hierarchy Process (AHP).}

AHP is an analysis used in decision making with a system approach, where decision makers try to understand a system's conditions and help make predictions in making decisions

\subsubsection{Stage of AHP Method}

From Analytical Hierarchy Process method there are some stages as follow :

1. Define the problem and determine the expected solution.

In this stage the author tries to determine the problem that the writer will solve clearly, in detail and easily understood [9]. From the problems that exist the author tries to determine the solution that might be suitable for the problem [10]. Solutions for problems may amount to more than one. The solution will be further developed by the author in the next stage [11].

2. Create a hierarchical structure that starts with the main goal.

After arranging the main goal as the top level, a hierarchy level will be arranged below the criteria that are suitable to consider or assess the alternatives that the author gives and determine the alternative [12]. Each criterion has a different intensity. The hierarchy is continued with subcriterion (if possible) [13].

3 . Create a paired comparison matrix that describes the relative contribution or influence of each element to the goal or criteria that are above it [14]. The matrix used is simple, has a strong position for a framework of consistency, obtains other information that may be needed with all possible comparisons and is able to analyze the sensitivity of overall priority for changing considerations [15]. The approach to the matrix reflects the dual aspects of priorities, which are dominating and dominated [16]. Comparison is based on judgment from decision makers by assessing the importance of an element compared to other elements. To start the pairwise comparison process, a criterion from the top level of the hierarchy is selected, for example $\mathrm{K}$ and then from the level below the elements to be compared are taken for example E1, E2, E3, E4, E5.

4. Define pairwise comparison so that the total number of judgments is $\mathrm{n} x[(\mathrm{n}-1)$ / 2], with $\mathrm{n}$ being the number of elements compared. The results of the comparison of each element will be a number from 1 to 9 which shows a comparison of the importance of an element. If an element in the matrix is compared to itself, the results of the comparison are given a value of 1. Scale 9 has proven to be acceptable and can distinguish intensity between elements. The results of the comparison are filled in cells that correspond to the elements compared. The scale of comparative pairings and their meanings introduced by Saaty can be seen below.

Intensity of interesr :

a. 1 means both elements are important. Two elements have same influence

b. 3 means one element is more important than other elements. Experience and assesment support one element than others.

c. 5 means one element is more important than other elements. Experience and assesment is very strong supporting an element than others.

d. 7 means one element is abosulutely more important than other elements. One element is very strong to be supported and dominant seen in practice.

e. 9 means one element is absoultely important than other elements. The supporting evidence of one element to other elements has hight affirmation level and other elements has one absoulte element than others. The evidence that supports one element and other elements has highest affirmation level that strenghten.

f. 2,4,6,8 means values between two values of contiguous considerations, 
This value is given if there are two compromises between 2 choices Reverse $=$ If $\mathrm{i}$ activity get one number compared to $\mathrm{j}$ activity , then $\mathrm{j}$ has the opposite value compared to $\mathrm{i}$.

2. Calculate eigen value and test its consistency

3. Calculate step 3,4 , and 5 for all hierarchy level.

4. Calculate eigen vector of each paired comparison matrix which is the weight of each element for prioritizing elements at the lowest hierarchy level until it reaches the goal. Calculations are done by summing the values of each column of the matrix, dividing each value from the column by the corresponding column to obtain the normalization of the matrix, and adding the values of each row and dividing it by the number of elements to get the average. 4. Check the consistency of the hierarchy [17]. That is measured in Analytical Hierarchy Process is the consistency ratio by looking at the consistency index [18]. The expected consistency is near perfect so as to produce a decision that is almost valid [19]. Although it is difficult to achieve perfect, the consistency ratio is expected to be less than or equal to $10 \%$.

The formula to determine consistency ratio (CR)

Consistency index from $\mathrm{n}$ ordo matrix can be obtained from formula :

$$
C I=\frac{\lambda \text { maksimum }-n}{n-1}
$$

where :

$\mathrm{CI}=$ Consistency Index

$\lambda$ maximum $=$ the greates eigen value of $\mathrm{n}$ ordo matrix

$\lambda$ maximum can be obtained by summing multiplication result with the number of main eigen vector.

If C.I $=0$, it means consistent matrix

The boundary of the inconsistency set. The time was measured by using a consistency ratio $(\mathrm{CR})$, which is the index comparison of consistency with random generator values (RI). The RI value depends on the order of $n$ matrix.

Table 1 : RI value

\begin{tabular}{|c|c|}
\hline $\mathrm{N}$ & $\mathrm{RI}$ \\
\hline 1 & 0.00 \\
\hline 2 & 0.00 \\
\hline 3 & 0.58 \\
\hline 4 & 0.90 \\
\hline 5 & 1.12 \\
\hline 6 & 1.24 \\
\hline 7 & 1.32 \\
\hline 8 & 1.41 \\
\hline 9 & 1.45 \\
\hline 10 & 1.49 \\
\hline 11 & 1.51 \\
\hline
\end{tabular}

$$
C R=\frac{C I}{R I}
$$

\section{RESEARCH METHODS}

In this research method we will discuss the flow of the best corn selection research process. The steps are as follows:

1. Conduct literature study about corn and its variety and Analytical Hierarchy Process (AHP) method.

2. Collect corn data that is recommended as best quality corn [20].

3. Perform system design from data analysis result to make it applicable using Analytical Hierarchy Process (AHP) method.

4. Conduct system development according to the need and system design [21].

5. Conduct the test of method to ensure method used is in accordance with expectation [22].

6. Decision making is based on system analysis result [23]

Problem solving process of decision support system in superior hybrid selection is as follows :

a. Collecting superior corn data.

b. Input criteria

c. make comparison table

d. Calculate weight criteria by normalizing each paired comparison matrix column by dividing each score of matrix column with the results of compatible column addition.

e. Perform hierarchy consistency test, if consistency is less than 0.1 so researcher needs to repeat the research.

f. If it is not less than 0.1 so it is obtained best quality corn.

In the Spearman Rank test, the correlation can be compared between the results of ranking between systems and experts. Before making a comparison, the first step is to make a hypothesis. The hypothesis used is the null hypothesis (H0) which means there is no relationship between the results of the system and experts. Another hypothesis is the alternative hypothesis (Ha) which is an alternative to the null hypothesis if it is not fulfilled. The alternative hypothesis is that relationship between the results of the system and experts.

The first step was to find the $\rho$ value. In this study the value of $\rho$ was 0.99754 and because the value of $n$ was more than 30 , the value of $\mathrm{z}$ was sought and compared with $\mathrm{z}$ table. In this study the significance level was determined to be $5 \%$. The $\mathrm{z}$ value in this study was 9.92539. With a significance level of $5 \%$, it is 


\section{Superior Hybrid Corn Variety Selection using AHP Method}

found that the lower limit of table $\mathrm{z}$ is -1.96 and the upper limit of table $\mathrm{z}$ is +1.96 . By comparing the values of $\mathrm{z}=$ 9.92539 and tables $\mathrm{z}=-1.96$ and +1.96 .

From the calculation above, it can be concluded that it did not fulfill the null $\mathrm{H} 0$ hypothesis and applied the alternative hypothesis $(\mathrm{Ha})$ which means that there was a relationship between the ranking of the system and the results of ranking experts. The relationship between the two samples is close to perfect relationship.

\section{CONCLUSION AND SUGGESTIONS}

\subsection{Conclusion}

Based on the problem observed and solved by this report, it can be concluded:

1. The creation process of decision support system in superior corn variety selection done by AHP method to determine criteria and weight in calculating systematically. 2. AHP method is decision support system process that can solve various problems in multi criteria decision making and it can be used to solve superior corn variety selection.

3. With real data and carried out through a systematic or scientific process, this system will provide information accurately and correctly.

\subsection{Suggestion}

Because of many limitations experienced by author so author suggests to:

1. Develop web-based system that is easier to be used by farmers to obtain information about superior hybrid corn.

2. In solving multi criteria problem using AHP method, it is not only one of decision making method, it is better to be performed other methods to support decision more effectively.

\section{REFERENCES}

1. Maseleno, A., Huda, M., Jasmi, K. A., Basiron, B., Mustari, I., Don, A. G., \& bin Ahmad, R. (2019). Hau-Kashyap approach for student's level of expertise. Egyptian Informatics Journal, 20(1), 27-32.

2. Maseleno, A., Huda, M., Siregar, M., Ahmad, R., Hehsan, A., Haron, Z., ... \& Jasmi, K. A. (2017). Combining the previous measure of evidence to educational entrance examination. Journal of Artificial Intelligence, 10(3), 85-90.

3. Jermsittiparsert, K., Siam, M., Issa, M., Ahmed, U., \& Pahi, M. 2019. "Do Consumers Expect Companies to Be Socially Responsible? The Impact of Corporate Social Responsibility on Buying Behavior." Uncertain Supply Chain Management 7 (4): 741-752.

4. Syazali, M., Putra, F., Rinaldi, A., Utami, L., Widayanti, Umam, R., \& Jermsittiparsert, K. 2019. "Partial Correlation Analysis Using Multiple Linear Regression: Impact on Business Environment of Digital Marketing Interest in the Era of Industrial Revolution 4.0." Management Science Letters 9 (11): 1875-1886.

5. Sae-Lim, P. \& Jermsittiparsert, K. 2019. "Is the Fourth Industrial Revolution a Panacea? Risks toward the Fourth Industrial Revolution: Evidence in the Thai Economy." International Journal of Innovation, Creativity and Change 5 (2): 732-752.

6. Chatchawanchanchanakij, P., Arpornpisal, C., \& Jermsittiparsert, K. 2019. "The Role of Corporate Governance in Creating a Capable Supply Chain: A Case of Indonesian Tin Industry.” International Journal of Supply Chain Management 8 (3): 854-864.

7. Hartinah, S., Suharso, P., Umam, R., Syazali, M., Lestari, B., Roslina, R., \& Jermsittiparsert, K. 2020. “Teacher's Performance Management: The Role of Principal's Leadership, Work Environment and Motivation in Tegal City, Indonesia." Management Science Letters 10 (1): 235-246.

8. Haseeb, M., Hussain, H., Slusarczyk, B., \& Jermsittiparsert, K. 2019 "Industry 4.0: A Solution towards Technology Challenges of Sustainable Business Performance.” Social Sciences 8 (5): 184.
9. Haseeb, M., Hussain, H., Kot, S., Androniceanu, A., \& Haseeb, M. Kot, S., Hussain, H., \& Jermsittiparsert, K. 2019. "Impact of Economic Growth, Environmental Pollution, and Energy Consumption on Health Expenditure and R and D Expenditure of ASEAN Countries.” Energies 12 (19): 3598.

10. Huda, S., Tsani, I., Syazali, M., Umam, R., \& Jermsittiparsert, K 2020. "The Management of Educational System Using Three Law Auguste Comte: A Case of Islamic Schools.” Management Science Letters 10 (3) (In press), DOI: 10.5267/j.msl.2019.9.018.

11. Usak, M., Kubiatko, M., Shabbir, M., Dudnik, O., Jermsittiparsert, K., \& Rajabion, L. 2019. "Health Care Service Delivery Based on the Internet of Things: A Systematic and Comprehensive Study." International Journal of Communication Systems 32 (14): e4179.

12. Jermsittiparsert, K., Ambarita, D., Mihardjo, L., \& Ghani, E. 2019. "Risk-Return through Financial Ratios as Determinants of Stock Price: A Study from ASEAN Region." Journal of Security and Sustainability Issues 9 (1): 199-210.

13. Thabhiranrak, T. \& Jermsittiparsert, K. 2019. "Towards Sustainable Functioning of Organization: Women Empowernment and Corporate Management Culture.” Journal of Security and Sustainability Issues 9 (1): 321-332.

14. Maseleno, A., Hardaker, G., Sabani, N., \& Suhaili, N. (2016). Data on multicultural education and diagnostic information profiling: Culture, learning styles and creativity. Data in brief, 9, 1048.

15. Chienwattanasook, K. \& Jermsittiparsert, K. 2019. "Impact of Entrepreneur Education on Entrepreneurial Self-Employment: A Case Study from Thailand." Polish Journal of Management Studies 19 (1): 106-116.

16. Jermsittiparsert, K., Sutduean, J., Sriyakul, T., \& Khumboon, R. 2019. "The Role of Customer Responsiveness in Improving the External Performance of an Agile Supply Chain." Polish Journal of Management Studies 19 (2): 206-217.

17. Jermsittiparsert, K., Sutduean, J., \& Sriyakul, T. 2019. "Effect of Service Innovation and Market Intelligence on Supply Chain Performance in Indonesian Fishing Industry." Industrial Engineering \& Management Systems 18 (3): 408-417.

18. Jermsittiparsert, K., Namdej, P., \& Somjai, S. 2019. “Green Supply Chain Practices and Sustainable Performance: Moderating Role of Total Quality Management Practices in Electronic Industry of Thailand." International Journal of Supply Chain Management 8 (3): 33-46.

19. Somjai, S. \& Jermsittiparsert, K. 2019. "The Trade-off between Cost and Environmental Performance in the Presence of Sustainable Supply Chain.” International Journal of Supply Chain Management 8 (4): 237-247.

20. Jermsittiparsert, K. \& Sawasdee, A. 2012. "Formal Education for Non-Thai or Undocumented Person in Thailand amidst the Challenge of Nationalism and Transnationalism: A Case Study of Wat Sirimongkhol School, Samut Sakhon Province." Kasetsart Journal - Social Sciences 33 (2): 203-213.

21. Chienwattanasook, K., Wattanapongphasuk, W., Prianto, A., \& Jermsittiparsert, K. 2019. "Corporate Entrepreneurship and Business Performance of Logistic Companies in Indonesia." Industrial Engineering \& Management Systems 18 (3): 538-547.

22. Dawabsheh, M., Hussein, A., \& Jermsittiparsert, K. 2019. "The Triangular Relationship between TQM, Organizational Excellence and Organizational Performance: A Case of Arab American University Palestine.” Management Science Letters 9 (6): 921-932.

23. Jermsittiparsert, K. 2019. "Role of Social and Technological Challenges in Achieving a Sustainable Competitive Advantage and Sustainable Business Performance.” Sustainability 11 (14): 3811. 